\title{
Experimental analysis of eccentrically loaded reinforced concrete columns with an added jacket of self-compacting concrete
}

\section{Análise experimental de pilares de concreto armado, com carga excêntrica, reforçados com chumbadores e concreto autoadensável}

\author{
J. P. VIRGENS a \\ jeovan2001@yahoo.com.br \\ https://orcid.org/0000-0002-8622-4624 \\ R. B. GOMES a \\ rbggomes@gmail.com \\ https://orcid.org/0000-0001-8613-9799 \\ L. M. TRAUTWEIN \\ leandromt@gmail.com \\ https://orcid.org/0000-0002-4631-9290 \\ G. N. GUIMARÃES a \\ rgilson.natal@gmail.com \\ https://orcid.org/0000-0003-1114-7318 \\ A. P. R. VAZ \\ anapaularvaz@hotmail.com \\ https://orcid.org/0000-0002-0467-0445
}

\begin{abstract}
This paper presents the experimental study of eccentrically loaded reinforced concrete columns with an added $35 \mathrm{~mm}$ self-compacting concrete jacket attached to the column's most compressed face using wedge bolts. Nine columns with a $2000 \mathrm{~mm}$ height were tested under compression and one-way bending until failure. Columns were denominated as original column (PO) with a cross section of $120 \mathrm{~mm} \times 250 \mathrm{~mm}$; reference column (PR) with a cross section of $155 \mathrm{~mm} \times 250 \mathrm{~mm}$, and seven columns with an initial cross section of $120 \mathrm{~mm} \times 250 \mathrm{~mm}$ and later reinforced by the addition of $35 \mathrm{~mm}$ self-compacting concrete layer and various configurations of wedge bolts. Except for the original column PO, the columns were submitted to a $42.5 \mathrm{~mm}$ load eccentricity due to the added concrete layer at the compressed face. Although failure of the wedge bolts did not occur, it was not possible to prevent detachment of the added layer. The results indicate that it is possible to structurally rehabilitate reinforce concrete columns with the use of the strengthening methodology used in this research, resulting in average ultimate load capacity gains of $271 \%$ compared to original column's ultimate load.
\end{abstract}

Keywords: column, structural reinforcement, self compacting concrete, wedge bolts.

\section{Resumo}

O presente trabalho apresenta o estudo experimental de pilares de concreto armado reforçados com parafusos chumbadores e acréscimo de camada com $35 \mathrm{~mm}$ de concreto autoadensável na face comprimida. Nove pilares, com alturas de $2000 \mathrm{~mm}$, foram submetidos à flexão composta reta com excentricidade inicial de $60 \mathrm{~mm}$, assim discriminados: um pilar original (PO) com seção transversal de $120 \mathrm{~mm} \times 250 \mathrm{~mm}$; um pilar de referência (PREF) com seção transversal de $155 \mathrm{~mm} \times 250 \mathrm{~mm}$ e sete pilares, inicialmente moldados com seção transversal de $120 \mathrm{~mm} \times 250$ $\mathrm{mm}$, e após, reforçados através da adição de camada de reforço de $35 \mathrm{~mm}$ e diversas configurações de posições de parafusos chumbadores na face comprimida. Exceto o pilar original (PO), os pilares foram submetidos à excentricidade inicial de carga de $42,5 \mathrm{~mm}$, devido ao acréscimo da camada de reforço na face comprimida. Apesar de não ocorrer ruptura dos parafusos chumbadores, não foi possível evitar o desplacamento da camada de reforço. Os resultados obtidos indicam que é possível a reabilitação estrutural de pilares de concreto armado com o uso da metodologia de reforço empregada, obtendo ganho de capacidade de carga média de $271 \%$ em relação ao pilar original (PO).

Palavras-chave: pilar, reforço estrutural, concreto autoadensável, parafusos chumbadores.

Saneamento de Goiás S/A, Structures Dept., Goiânia, GO, Brazil. 


\section{Introduction}

A column failure can lead to the failure of part or the entire structure, which is an undesirable fact to any structural engineer. Several causes can lead to a reinforced concrete column failure: imprudence, negligence, neglectfulness in design or construction; construction flaws; deterioration due to attack by aggressive agents; lack of preventive or corrective maintenance; incorrect structural use, etc. A structure can be repaired, when it is rehabilitated and returns to its normal conditions of use, or it can be retrofitted when the structure is already under normal use but it's structural load capacity must be increased due to, for example, changes in building usage. Increasing the concrete cross section by using a concrete jacket, which may include additional steel reinforcement, is a common technique for structural repair and rehabilitation used in Brazil.

\subsection{Research significance}

This experimental research of retrofitted columns will help structural engineers and other professionals with more scientific knowledge to deal with this situation in a safer and more economical way. This work aims to study the behavior of retrofitted columns when adding an extra layer of self-compacting concrete to the most compressed face of a reinforced concrete column subjected to axial force and uniaxial bending. A substrate surface preparation using waterblasting and the installation of wedge bolts, with different diameters and positioning, were used to avoid detachment of the added concrete layer and to increase bond with the substrate.

\section{Literature review}

Several works have been done on the study of the behavior of retrofitted columns. Among recent researchers in Brazil, one can include Adorno [2], Araújo [4], Omar [14] and Sahb [16].

Adorno's [2] research involved an experimental study of reinforced and plain concrete columns subjected to one-way bending and axial load. One of his objectives was to validate a theory proposed by
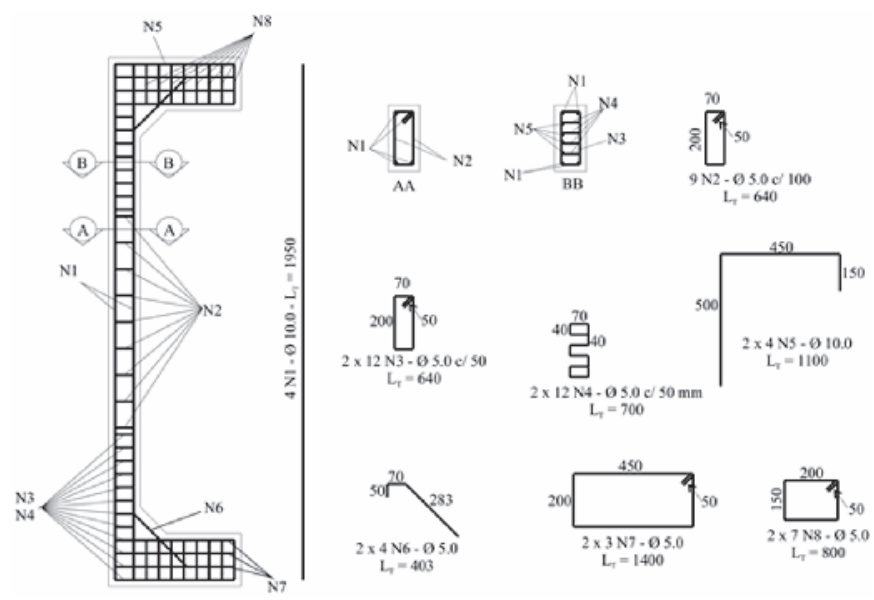

Figure 1

Details of column reinforcement
Melo [13] which aims to provide aa analytical solution to non-linear equations that govern the equilibrium conditions and strength of the column's cross section. Among other conclusions, Adorno observed that for all his columns the digital indicator at column midheight had the largest displacements, top column displacement was less than bottom column displacement due to load application at the column's bottom, and the increase in the axial force's initial eccentricity increased concrete compressive strains.

Araújo [4] tested nine concrete columns subjected to compression and uniaxial bending. His experimental program was done in three series of columns named PSA, PCA4 and PCA6. Column series PSA involved testing plain concrete columns. Series PCA4 and PCA6 involved reinforced concrete with four or six 10-mm diameter steel rebars, respectively, as longitudinal steel reinforcement and column sizes and shapes the same as Adorno [2]. Initial eccentricity varied and was equal to $40 \mathrm{~mm}, 50 \mathrm{~mm}$ and $60 \mathrm{~mm}$. Araújo [4] makes conclusions on the influence of steel reinforcement ratio on strains and displacements. PCA6 columns showed smaller tension strains than those columns of series PCA4 for all eccentricities; mid-height displacements for PCA4 columns were largest and these displacements were smallest for plain concrete columns due to their fragile failure.

Omar [14] studied reinforced concrete columns subjected to compression and one-way bending and retrofitted with a self-compacting concrete (SCC) jacket and installation of connecting stirrups on the tension and compression faces. Eight columns were tested with a $120 \mathrm{~mm}$ by $250 \mathrm{~mm}$ cross section, $2000 \mathrm{~mm}$ height, initial eccentricity of $42.5 \mathrm{~mm}$, cast with 28-day compressive strength of $30 \mathrm{MPa}$ and had four $10-\mathrm{mm}$ diameter steel rebars as longitudinal reinforcement. Two columns (named P1 and P2) were taken as references and were tested until failure. The other six (named columns P3 to P8) were tested until a previously defined load (close to yield load), then were retrofitted and retested until failure. Omar [14] concludes that the retrofitted columns had an ultimate load twice that of the reference columns, confirming the efficiency of the retrofit. Only columns with a retrofit jacket placed on the compression face (columns PC35 e PC55) had detachment of the added concrete layer indicating bond between the substrate concrete and the added layer must be improved.

Based on the results of Omar [14], Sahb [16] proposed a similar study with wedge bolts instead of connecting stirrups to increase bond between the concrete layers to reduce concrete detachment of the added layer. Results indicate retrofitted columns had higher ultimate loads compared to the reference columns confirming the satisfactory performance of the retrofit method. Some columns had a fragile failure with detachment of the added concrete layer. Detachment was delayed with the use of more wedge bolts. The column with the most wedge bolts failed with detachment of the added concrete layer and there was evidence of concrete crushing at column mid-height.

\section{Experimental program}

Development of this research was based on previous work done by Adorno [2], Omar [14] and Sahb [16]. The columns tested and the test setup had the same basic properties as their work, such 


\section{Table 1}

Column characteristics

\begin{tabular}{cccccc}
\hline Denomination & $\begin{array}{c}\text { Size of } \\
\text { cross section } \\
(\mathbf{m m})\end{array}$ & $\begin{array}{c}\text { Number of } \\
\text { wedge bolts }\end{array}$ & $\begin{array}{c}\mathbf{T}_{\text {ch }} \\
(\%)\end{array}$ & $\begin{array}{c}\mathbf{E}_{\mathrm{ref}} \\
(\mathbf{m m})\end{array}$ & $\begin{array}{c}\mathbf{e}_{\mathrm{i}} \\
(\mathbf{m m})\end{array}$ \\
\hline Column PO & $120 \times 250$ & - & - & - & 60.0 \\
Column PREF & $155 \times 250$ & - & - & - & 45 \\
Column PAF-150-18 & $155 \times 250$ & 18 & 0.25 & 35 & 42.5 \\
Column PAF-150-26 & $155 \times 250$ & 26 & 0.36 & 35 & 42.5 \\
Column PPBA-150-18 & $155 \times 250$ & 18 & 0.65 & 35 \\
Column PPBA-150-18-Ch & $155 \times 250$ & 18 & 0.36 & 35 & 42.5 \\
Column PPBA150-26 & $155 \times 250$ & 26 & 0.48 & 35 & 42.5 \\
Column PPBA-150-34 & $155 \times 250$ & 34 & 0.48 & 35 & 42.5 \\
Column PPBA-150-34-SP & $155 \times 250$ & 34 & & 42.5 \\
\hline
\end{tabular}

$T_{c h}$ : Wedge bolt ratio $\left(\left(A_{\text {bolt }} / A_{\text {int }}\right) \times 100\right)$, where $A_{\text {bolt }}$ is the total cross sectional area of all bolts and $A_{\text {int }}$ is the surface area of the substrate-added layer interface.

$E_{\text {ref: }}$ : thickness of the added concrete layer; $e_{i}$ : initial eccentricity; $C$ : plate with shear pins; SP: wedge bolts without nuts and washers.

as: concrete cross section, steel reinforcement, connector type, type of concrete and casting procedure.

Tests were done on nine columns cast with a $40 \mathrm{MPa} 28$-day compressive strength self-compacting concrete. Columns were subjected to uniaxial bending and axial load and $10 \mathrm{~mm}$ diameter steel rebars were used for steel reinforcement. Details of the steel reinforcement are shown in Figure 1. The specimens were built with two corbels, one at the base and another at the top of the column, to avoid stress concentrations due to load application and to allow application of a vertical force with an eccentricity that will provide bending moment at the column mid-height so that the column will be under compression and uniaxial bending. Column length was $2000 \mathrm{~mm}$.

Columns were retrofitted with a SCC jacket at the most compressed face. The jacket consists of one $35 \mathrm{~mm}$ thick layer of concrete. Originally, column cross section was $120 \mathrm{~mm}$ by $250 \mathrm{~mm}$ and was increased to $155 \mathrm{~mm}$ by $250 \mathrm{~mm}$ with the added layer. Wedge bolts were used along its length to increase adhesion between the old concrete substrate and the new concrete layer.

Columns were named PO (original column), PREF (reference column),
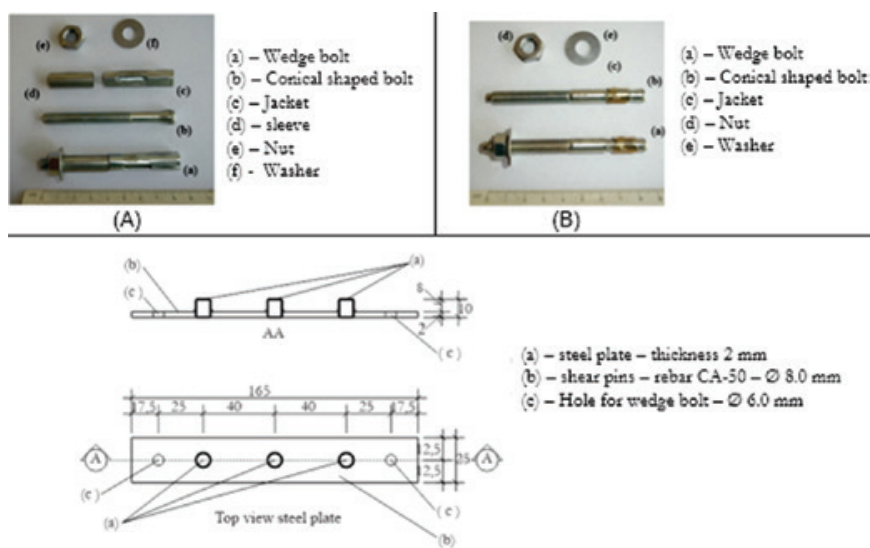

(C)

Figure 2

(A) e (B) Details of wedge bolts;

(C) Details of steel plate
PAF (2 columns) and PPBA ( 5 columns). The original column PO was tested with and initial eccentricity of $60 \mathrm{~mm}$ and had $120 \mathrm{~mm}$ by 250 $\mathrm{mm}$ cross section. The reference column PREF was cast with a cross section of $155 \mathrm{~mm}$ by $250 \mathrm{~mm}$. Both columns PO and PREF were not retrofitted. Columns PAF and PPBA were all cast with a $120 \mathrm{~mm}$ by $250 \mathrm{~mm}$ cross section and were later retrofitted with an added concrete layer of $35 \mathrm{~mm}$ on the most compressed face. Size of the cross section for these columns when tested were $155 \mathrm{~mm}$ by $250 \mathrm{~mm}$. Except for column PO, all other columns were tested with an initial eccentricity of $42.5 \mathrm{~mm}$. Column characteristics are shown in Table 1.

Columns PAF-150-18 and PAF-150-26 were retrofitted using wedge bolts model Alfa 5/16X80, with a nominal diameter of $8 \mathrm{~mm}$ and $80 \mathrm{~mm}$ effective length (Figure 2-A). Columns PPBA used wedge bolts type PPBA 5/16X3.1/4-C/P, with a nominal diameter of $6 \mathrm{~mm}$ and $80 \mathrm{~mm}$ effective length (Figure 2-B). A steel plate with 3 connectors was used in column PPBA-150-18-Ch (Figure 2-C). Column PPBA-150-34-SP has the same characteristics as column
Column PAF-150-18

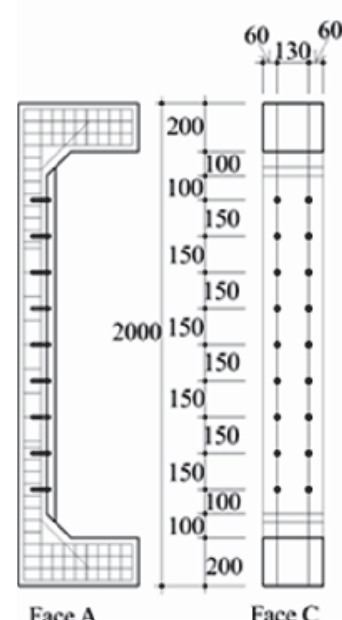

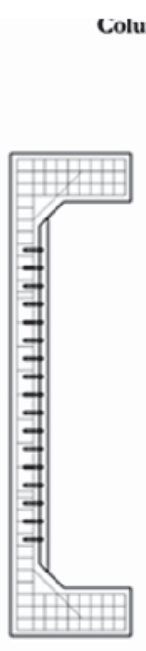

Face A
Column PAr-150-20

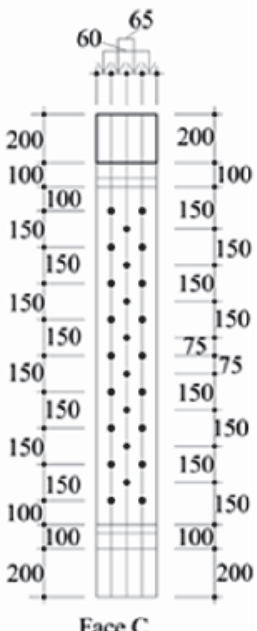

Figure 3

Wedge bolt positioning in columns PAF-150-18 and PAF-150-26 (dimensions in $\mathrm{mm}$ ) 


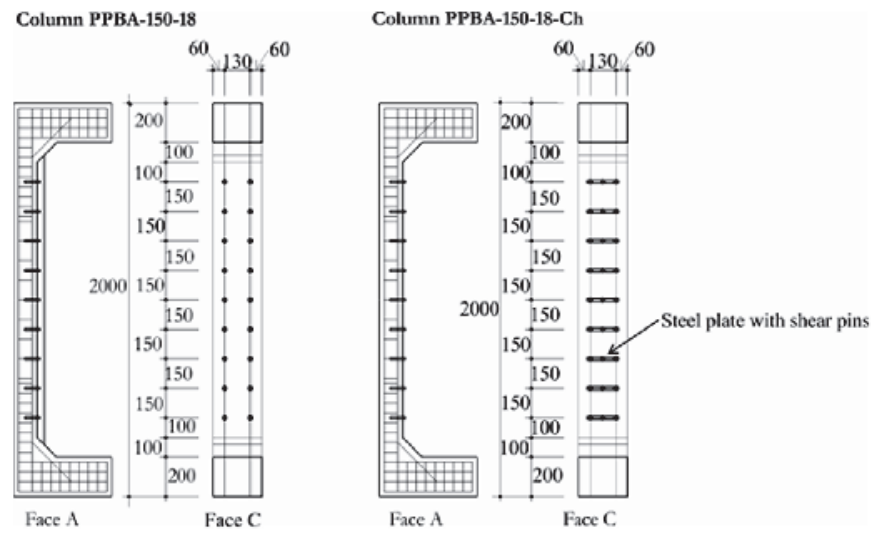

Figure 4

Wedge bolt positioning in columns PPBA-150-18 and PPBA-150-18-Ch
Column PPBA-150-26

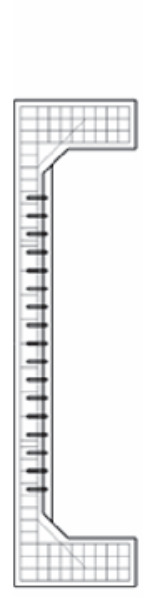

Face A

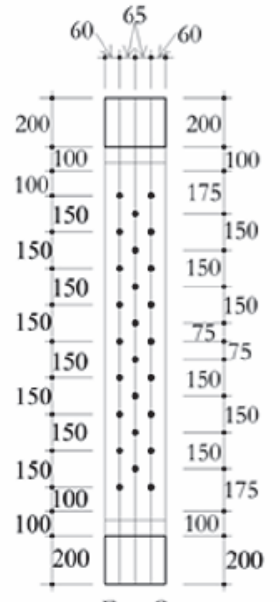

Face C
Column PPBA-150-34

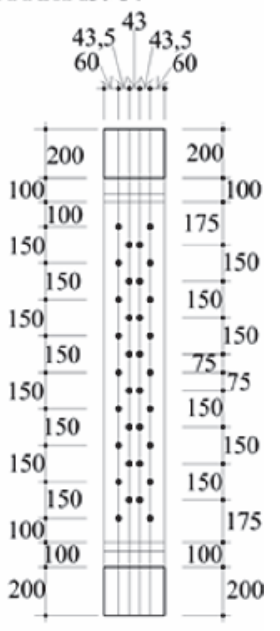

Face A

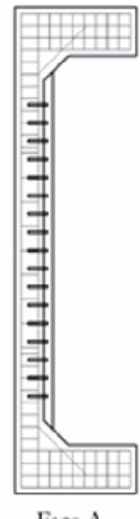

Face C

\section{Figure 5}

Wedge bolt positioning in columns PPBA-150-26 and PPBA-150-34 (same as in column PPBA-150-34-SP)

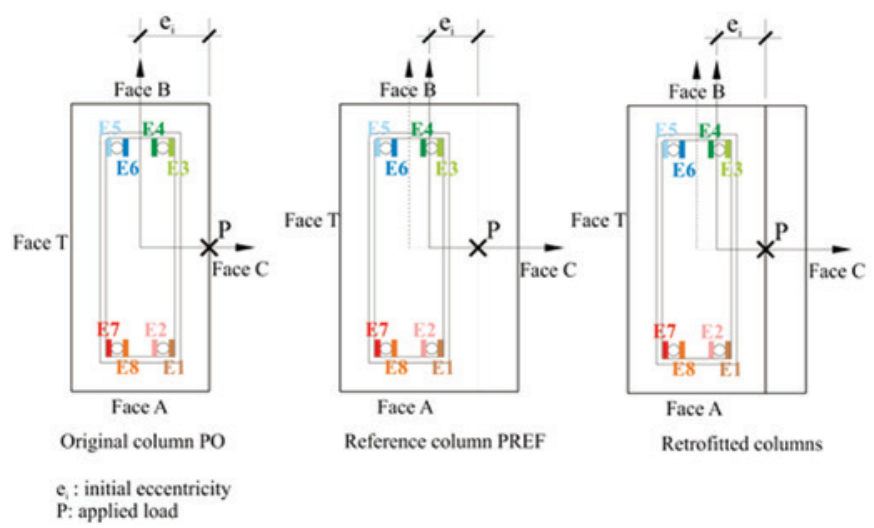

Figure 6

Strain gauge positioning in longitudinal steel
PPBA-150-34, except for the absence of nuts and washers. All wedge bolts were fabricated by Âncora Sistemas de Fixação Ltda. Column denominations, quantity of wedge bolts, wedge bolt reinforcing ratio and initial eccentricities are shown in Table 1 . Wedge bolt detailing and positioning are shown in Figures 3 through 5 .

Electrical resistance strain gauges positioned along the steel reinforcement and on the concrete surface at column mid-height were used to measure strains on the steel and concrete surface respectively as shown in Figures 6 and 7. Strain gages for concrete were installed at the cross section's most compressed face.

Two casts were made using self-compacting concrete. Columns with the original dimensions and the reference column were cast first, and the strengthening layer was added in a second cast. No specimens were tested before the second cast. Specific testing on the fresh self-compacting concrete was done namely: slump test, $V$-funnel test and L-Box test.

Preparation and casting of the added SCC layer was done in several stages and included: substrate surface treatment with water blasting, wedge bolt installation using power drill (care was taken

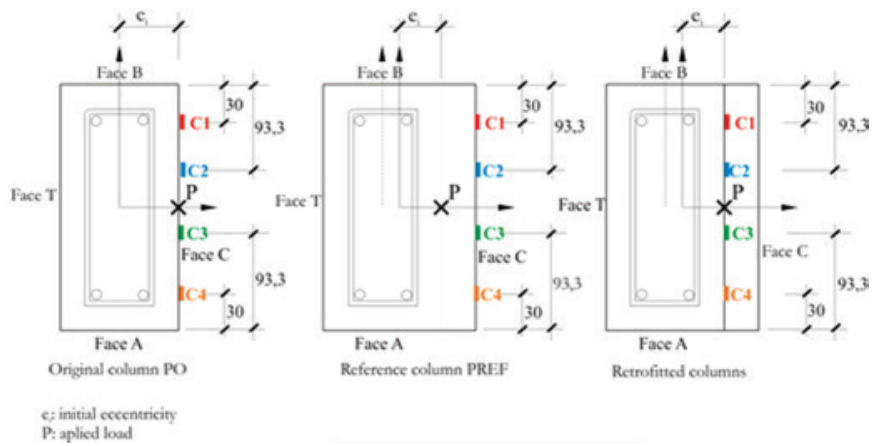

Figure 7

Concrete strain gauge positioning

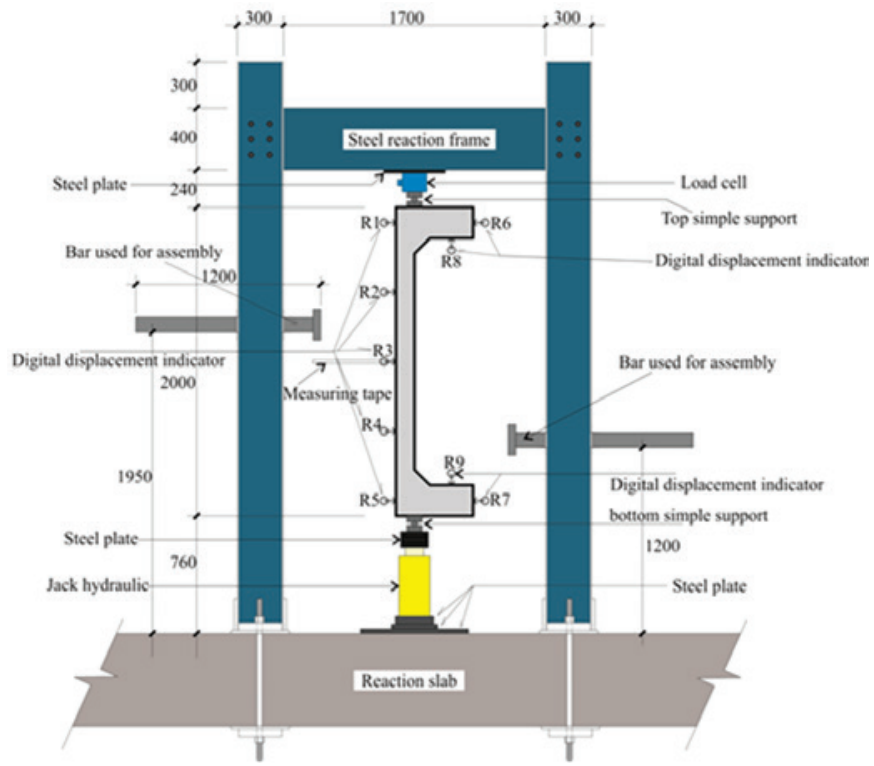

Figure 8

Testing setup 
to place bolts without disturbing existing rebars and stirrups), formwork placement for new concrete layer, cleaning and wetting of concrete substrate before finally casting of the added layer.

Figure 8 presents the test setup which is basically the column attached to a steel frame on a reaction slab. Vertical load application was done using a hydraulic jack with a $300 \mathrm{kN}$ capacity attached to a manual hydraulic pump. The hydraulic jack was placed under the column on the reaction slab. A $300 \mathrm{kN}$ capacity load cell was placed at the column's top. All strains and load cell readings are recorded digitally on a microcomputer.

Horizontal and vertical displacements were measured by digital displacement indicators also shown in Figure 8. Indicators had a $0.01 \mathrm{~mm}$ precision and a $50 \mathrm{~mm}$ gauge length. Displacements were measured on the tension face (indicators R1 through R5), on the top corbel (indicators R6 and R8) and bottom corbel (indicators R7 and R9). Mid-height horizontal displacement was measured with indicator R3 and an additional measuring tape was used since some of the testing equipment was removed just prior to failure to avoid damage.

\section{Results and discussion}

\subsection{Material properties}

Concrete compressive strength testing was done using cylindrical specimens with a $150 \mathrm{~mm}$ diameter and $300 \mathrm{~mm}$ height according to procedures in code ABNT [6]. Concrete compressive strength on testing day for both substrate and the added layer are shown in Table 1 for all columns.

Tension tests were done to characterize the steel reinforcement according to code ABNT [7]. Results for steel yielding, yielding strain and modulus of elasticity are shown in Table 2 for each rebar diameter.

\subsection{Loads and modes of failure}

Table 3 shows ultimate loads $P_{u}$ and modes of failure for all columns. Also shown is the ratio of the column's ultimate load to the original column's (PO) ultimate load expressed by
Table 2

Steel structural properties

\begin{tabular}{cccc}
\hline $\begin{array}{c}\text { Bar diameter } \\
(\mathrm{mm})\end{array}$ & $\mathrm{f}_{\mathrm{y}}(\mathrm{MPa})$ & $\varepsilon_{\mathrm{y}}(\mathrm{mm} / \mathrm{m})$ & $\mathrm{E}_{\mathrm{s}}(\mathrm{GPa})$ \\
\hline 5 & 727 & 2.80 & 260 \\
8 & 562 & 2.61 & 215 \\
10 & 584 & 2.78 & 210 \\
\hline
\end{tabular}

$\mathrm{f}_{\mathrm{y}}$ : yield stress; $\varepsilon_{\mathrm{y}}$ : yield strain; $\mathrm{E}_{\mathrm{s}}$ : modulus of elasticity.

$\mathrm{P}_{\mathrm{u}} / \mathrm{P}_{\mathrm{u}} \mathrm{PO}$ and the ratio of the column's ultimate load to the reference column's (PREF) ultimate load expressed by $\mathrm{P}_{\mathrm{u}} / \mathrm{P}_{\mathrm{u}}$ PREF. Table 3 also shows the ratio of the maximum steel strain to the yielding strain $\left(\varepsilon_{\mathrm{s}, \mathrm{max}} / \varepsilon_{\mathrm{y}}\right)$ and the ratio of the maximum concrete strain to the ultimate concrete strain $\left(\varepsilon_{\mathrm{c}, \max } / \varepsilon_{\mathrm{u}}\right)$.

The reference column PREF showed the highest ultimate load and was 4.28 times the original column's (PO) ultimate load. Retrofitted columns presented ultimate load capacity ranging from 2.68 to 4.19 the ultimate load of the original column PO. However, none of them surpassed the reference column PREF's ultimate load. Difference in concrete compressive strength of the substrate and the added layer concretes was not more than $2.4 \mathrm{MPa}$, which represents a maximum difference of $5 \%$ relative to the substrate concrete.

Steel strains showed steel yielding in columns PO, PAF-150-18, PPBA-150-18 and PPBA-150-34-SP. For other columns, no steel yielding occurred and the ratio of maximum steel strain to the yielding strain was between 0.43 and 0.90 .

Although ultimate load increased with an increase in the number of wedge bolts (shown in Table 1), the wedge bolts did not prevent detachment of the added concrete layer. All retrofitted columns had a fragile failure with detachment of the added layer, although steel yielding occurred in some of the columns. No type of failure was observed in any of the wedge bolts.

\subsection{Displacements}

Figure 9 show load versus mid-height horizontal displacement curves for all columns. Also shown, in the corner of the figure, are the column's ultimate load $\mathrm{P}_{\mathrm{u}}$ and a schematic drawing of

Table 3

Loads and modes of failure

\begin{tabular}{|c|c|c|c|c|c|c|c|c|}
\hline Column & $\begin{array}{c}\mathrm{P}_{\mathrm{u}} \\
(\mathrm{kN})\end{array}$ & $\begin{array}{c}\mathbf{P}_{\mathrm{u}} \\
\mathbf{P}_{\mathrm{u}}\end{array}$ & $\frac{\mathbf{P}_{\mathrm{u}}}{\mathbf{P}_{\mathrm{u}} \mathrm{PREF}}$ & $\begin{array}{c}F_{c}^{\text {sub }} \\
(\mathrm{MPa})\end{array}$ & $\begin{array}{c}F_{c}^{\text {lay }} \\
(\mathrm{MPa})\end{array}$ & $\frac{\varepsilon_{\mathrm{s}, \max }}{\varepsilon_{\mathrm{y}}}$ & $\frac{\varepsilon_{\mathrm{c}, \max }}{\varepsilon_{\mathrm{u}}}$ & $\begin{array}{c}\text { Mode } \\
\text { of failure }\end{array}$ \\
\hline Column PO & 126.7 & 1 & 0.23 & 41.9 & - & $>1$ & 0.82 & SY-CC \\
\hline Column PREF & 542.2 & 4.28 & 1 & 41.3 & - & 0.56 & 0.60 & SY-CC \\
\hline Column PAF-150-18 & 453.2 & 2.68 & 0.84 & 41.4 & 39.7 & $>1$ & 0.77 & $\mathrm{DL}$ \\
\hline Column PAF-150-26 & 442.5 & 3.49 & 0.82 & 41.5 & 40.1 & 0.81 & 0.97 & $\mathrm{DL}$ \\
\hline Column PPBA-150-18 & 390.8 & 3.08 & 0.72 & 42.8 & 44.0 & $>1$ & 0.91 & $\mathrm{DL}$ \\
\hline Column PPBA-150-18-Ch & 427.2 & 3.37 & 0.79 & 43.8 & 46.2 & 0.43 & 0.71 & DL \\
\hline Column PPBA-150-26 & 517.1 & 4.08 & 0.95 & 43.0 & 44.4 & 0.90 & $>1$ & $\mathrm{DL}$ \\
\hline Column PPBA-150-34 & 528.3 & 4.17 & 0.97 & 43.2 & 44.6 & 0.65 & 0.90 & $\mathrm{DL}$ \\
\hline Column PPBA-150-34-SP & 531.0 & 4.19 & 0.98 & 43.6 & 45.9 & $>1$ & 0.99 & $\mathrm{DL}$ \\
\hline
\end{tabular}

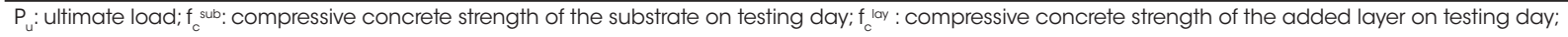
$\varepsilon_{\mathrm{s}, \max }$ : maximum steel strain in rebars; $\varepsilon_{\mathrm{y}}$ : steel yielding strain; $\varepsilon_{\mathrm{c}, \max }$ : maximum concrete strain; $\varepsilon_{\mathrm{u}}$ : ultimate concrete strain; SY: steel yielding; CC: concrete crushing; DL: detachment of the added concrete layer. 


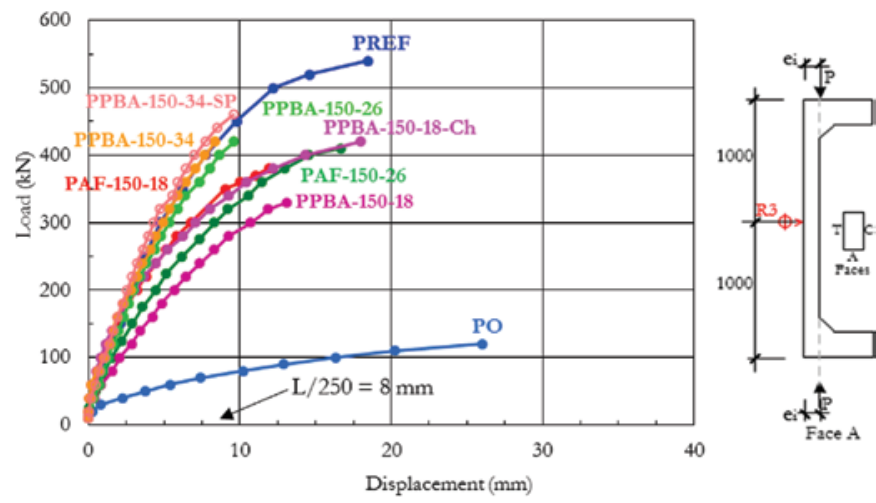

Figure 9

Load versus displacement curves for indicator R3

indicator positioning. Mid-height displacements were the largest of all measured displacements for all columns as expected. Although not shown in the figure, displacements measured at the bottom corbel (indicators R7 and R9) were larger than the displacements measured at the top corbel (indicators R6 and R8), possibly due to greater stress concentrations at the bottom corbel where load was applied with the hydraulic jack.

Original column PO presented the smallest ultimate load and the largest displacement. Its ultimate load was $126.7 \mathrm{kN}$ for a $26.0 \mathrm{~mm}$ mid-height displacement for indicator R3. Measuring tape indicated a reading of $34.2 \mathrm{~mm}$ (not shown in the figure). Reference column PREF failed with the largest ultimate load of $542.2 \mathrm{kN}$ with midheight displacement of $11.9 \mathrm{~mm}$ and $13.1 \mathrm{~mm}$ measured by the displacement indicator R3 and the measuring tape, respectively.

There are no prescribed limits for horizontal column displacements at service loads in the Brazilian code NBR 6118 (ABNT [5]) but, in this study, the limiting value of L/250, corresponding to $8 \mathrm{~mm}$, was used ( $L$ is span length). This code parameter of $L / 250$ is used for limiting displacements for sensorial acceptance for structural elements at service loads. Therefore, no column displacement should exceed this value for service loads. From data in Figure 9, column PO exceeded this service load displacement limit at $57 \%$ of the

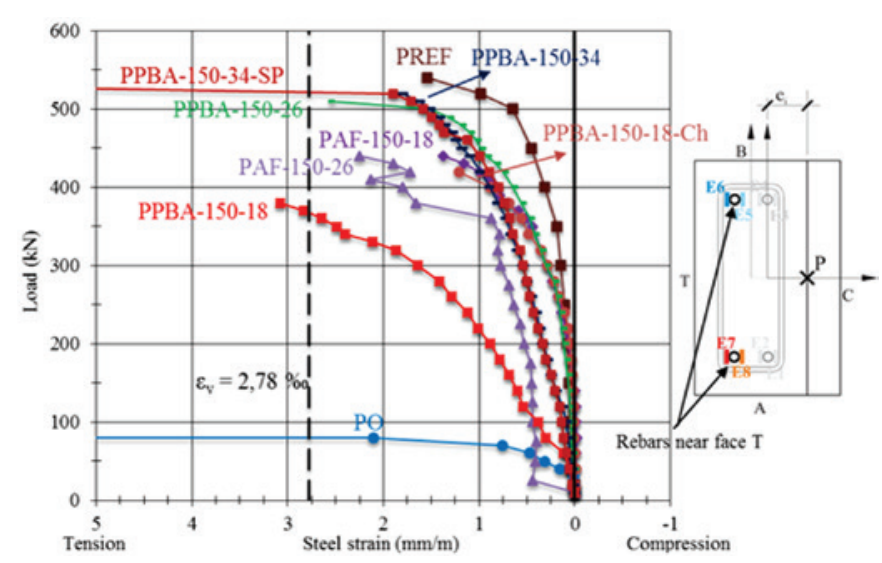

Figure 10

Load versus maximum steel strains ultimate load. Column PPBA-150-34-SP exceed the service load displacement limit at $80 \%$ of the ultimate load. Other columns had results between the values for these two columns and ranged from $66 \%$ to $75 \%$ of the ultimate load.

\subsection{Steel tension strains}

Figure 10 shows load versus maximum tension steel strains for all columns. Also shown is a schematic drawing of strain gage position on the tension rebars. The strain readings used for this curve is the highest strain for all four strain gages placed on the rebars (column face T). Steel yielding occurred for strains over $2.78 \%$ (dotted line shown in figure).

Highest tension strains occurred in rebars of columns PO, PPBA150-18 and PPBA-150-34SP, where steel yielded. The smallest strains occurred in columns PBA-150-18-Ch and PAF-150-18 with strains of $1.21 \mathrm{~mm} / \mathrm{m}$ and $1.38 \mathrm{~mm} / \mathrm{m}$, respectively, which corresponds to about $45 \%$ of yield strain. Steel reinforcement in other columns did not reach yield strain, but the load-steel strain curve inclination started to decrease as the column failed.

\subsection{Concrete compressive strains}

Figure 11 shows load versus maximum concrete compressive strains for all columns. Also shown is a schematic drawing of strain gage position on the concrete surface of the most compressed face of the column (Face $\mathrm{C}$ ). The strain readings used for this curve is the highest strain for all four strain gages placed on Face C. In this study, ACl's ultimate concrete strain of $3.0 \%$ was used as reference $(\mathrm{ACl}[1])$.

Original column PO had the smallest inclination of the load-strain curve. Maximum concrete strain in this column was $2.86 \mathrm{~mm} / \mathrm{m}$ which is evidence of concrete crushing failure since this reading was taken at a load prior to the ultimate failure load.

All retrofitted columns, with the exception of columns PAF-150-18 and PPBA-150-18-Ch, showed maximum concrete strains larger than ACl's ultimate concrete strain. Columns PPBA-150-34, PPBA150-34-SP, PAF-150-26 and PPBA-150-26 showed maximum compressive strains of $3.16 \mathrm{~mm} / \mathrm{m}, 3.30 \mathrm{~mm} / \mathrm{m}, 3.38 \mathrm{~mm} / \mathrm{m}$ and 3.88

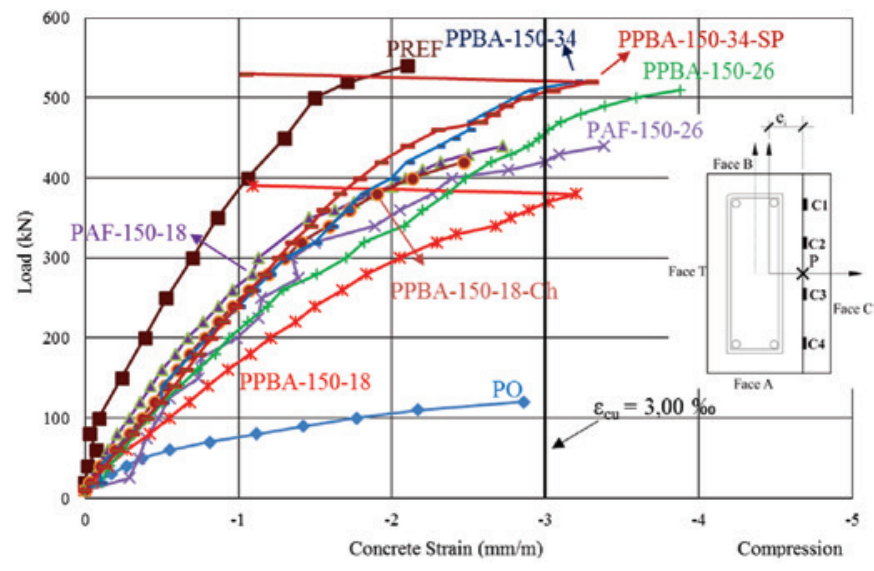

Figure 11

Load versus maximum concrete strains 
$\mathrm{mm} / \mathrm{m}$, respectively, all higher than ACl's ultimate concrete strain. Maximum concrete strains in column PREF did not reach the $\mathrm{ACl}$ limit, but its load-strain curve's inclination started to decrease at

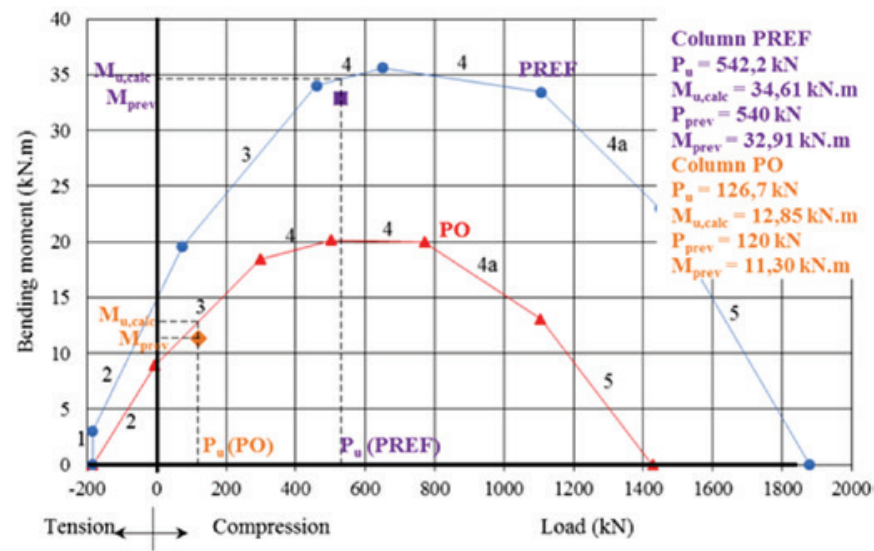

\section{Figure 12}

$\mathrm{N}-\mathrm{M}$ Interaction diagram for column PO and column PREF

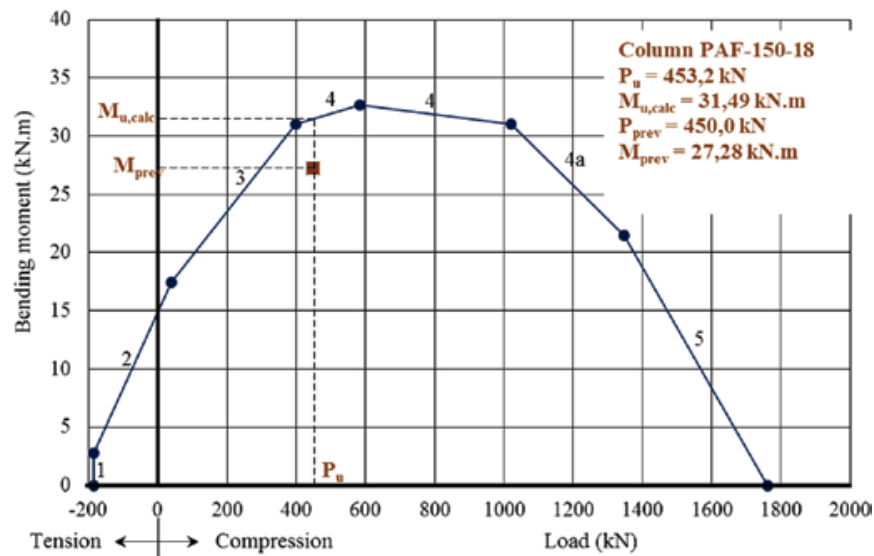

\section{Figure 13}

N-M Interaction diagram for column PAF-150-18

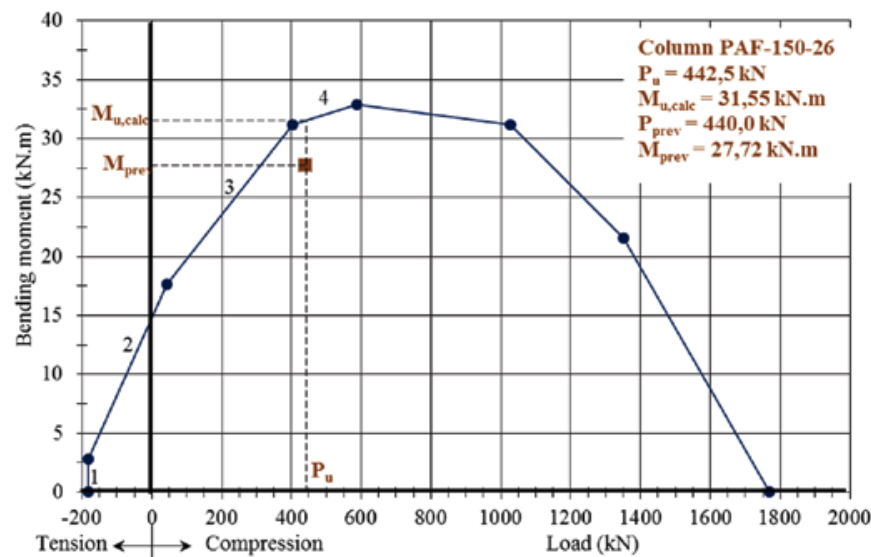

Figure 14

N-M Interaction diagram for column PAF-150-26 higher loads. Maximum concrete strain was $2.1 \mathrm{~mm} / \mathrm{m}$ at a load of $540 \mathrm{kN}$; still $30 \%$ below the $\mathrm{ACl}$ ultimate concrete strain limit.

\subsection{Axial force versus moment interaction diagram (N-M)}

Figures 12 through 16 shown axial force versus bending moment interaction diagram for some of the columns of this study. Prescriptions in Brazilian code NBR 6118 (ABNT [5]) were used to establish ultimate limit state domains 1 through 5 in the interaction diagrams where ultimate concrete strain $\left(\varepsilon_{\mathrm{cu}}\right)$ was considered to be 0.003 and steel yielding at strains of 0.00278 according to properties of the steel of this study. The figures also show the bending moment $M_{\text {prev }}$ which corresponds to the moment at the load reading $\left(P_{\text {prev }}\right)$ immediately before the ultimate load $P_{u}$. Bending moment $\mathrm{M}_{\mathrm{u}, \mathrm{calc}}$ corresponds to the calculated bending moment at the ultimate load $\mathrm{P}_{\mathrm{u}}$.

Figure 12 shows $\mathrm{N}-\mathrm{M}$ interaction diagrams for the original column $\mathrm{PO}$ and reference column PREF. Column PO failed in domain 3 and the difference between bending moments $\mathrm{M}_{\text {prev }}$ and $\mathrm{M}_{\mathrm{u}, \mathrm{calc}}$ was $12 \%$. Column PO failed in a region of the N-M diagram close to

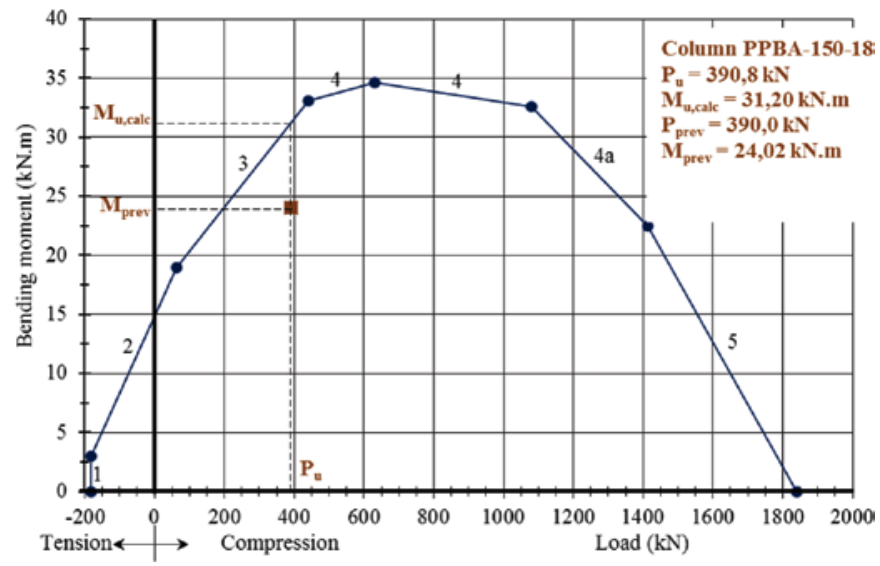

Figure 15

N-M Interaction diagram for column PPBA-150-18

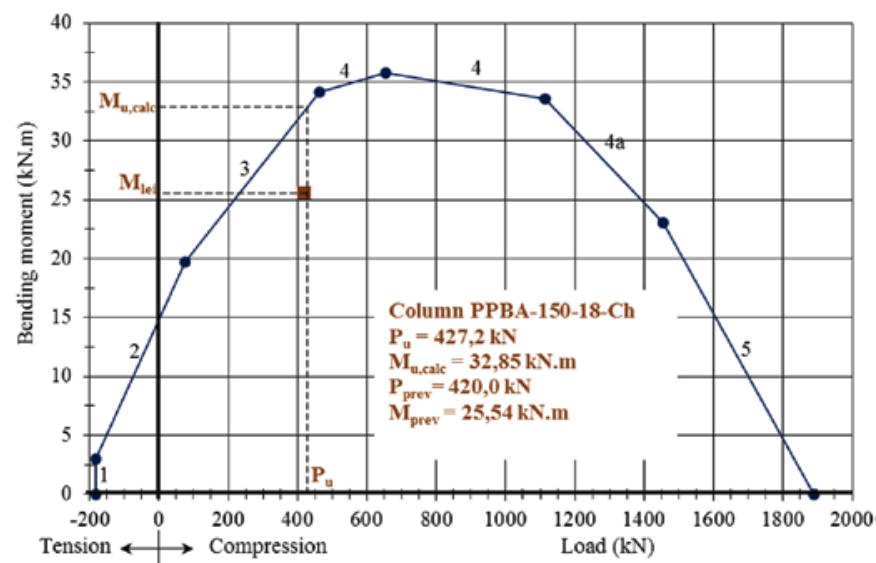

Figure 16

N-M Interaction diagram for column PPBA-150-18-Ch 
the $y$-axis (axial force equals to zero), which indicates it is almost behaves as a beam with compression reinforcement and that may explain both the steel yielding and the compressive concrete crushing. Reference column PREF failed in domain 4 and the difference between bending moments $M_{\text {prev }}$ and $M_{u, \text { calc }}$ was $5 \%$. Retrofitted columns PAF-150-18 e PAF-150-26 failed in domain 4 and the difference between bending moments $M_{\text {prev }}$ and $M_{u \text { calc }}$ was $15.4 \%$ and $13.6 \%$, respectively (Figures 13 and 14). Columns PPBA-150-18 and PPBA-150-18-Ch failed under the smallest ultimate loads, about $75 \%$ of the reference column's ultimate load (Figures 15 and 16). Both failures occurred in domain 3. Concrete detachment of the added layer probably reduced the load gain and failure occurred at a load smaller than expected, which would be the ultimate load of the reference column.

Columns failed in ultimate limit state domains 3 or 4 of the N-M interaction diagram. In these domains, an increase in ultimate bending moment would naturally be followed by an increase in ultimate load.

\section{Conclusions}

Considering the limitations of this study, the most important conclusions are:

- All retrofitted columns failed at ultimate loads higher than the original column $\mathrm{PO}$, suggesting the retrofit technique is satisfactory.

- The increase is the quantity of wedge bolts increased the failure load but did not prevent detachment of the added layer of concrete, although steel yielding and concrete crushing occurred in some columns (PAF-150-34 and PPBA-150-34-SP).

- Retrofitted columns had reduced horizontal displacements as a function of the number of wedge bolts, gaining rigidity.

- A fragile failure occurred in the retrofitted columns and detachment of the added concrete layer was not prevented but a some ductile behavior was observed and steel strains were close to or above steel yielding strains.

- Self-compacting concrete worked well during casting and did not segregate and concrete casting voids did not appear.

- Wedge bolts did not fail in shear or bond, suggesting they may be used for retrofitting techniques.

Columns failing in domains 3 or 4 of the N-M interaction diagram is a limitation of this study. In these domains, an increase in ultimate bending moment would naturally be followed by an increase in ultimate load.

\section{Acknowledgements}

The authors wish to thank to financial contributions of the Brazilian government through its research agencies CAPES/PROCAD and $\mathrm{CNPq}$ and the contribution of private companies such as Realmix, Carlos Campos Consultoria e Construções Limitada and Impercia, for their donation of manpower, equipment and materials.

\section{References}

[1] ACI COMMITTEE 318. Buiding Code Requirements for Reinforced Concrete and Commentary - ACl 318M. Detroit, American Concrete Institute, 2014.
[2] ADORNO, A. L. C. Análise Teórica e Experimental de Pilares em Concreto Simples e Armado sob Flexo-Compressão Reta. Tese de Doutorado. Departamento de Engenharia Civil e Ambiental, UnB, Brasília, DF, 399p, 2004.

[3] ANCORA SISTEMA DE FIXAÇÃO. Catálogo Completo. 2013. Disponível em: <http://www.ancora.com.br/ site/?portfolio/>. Acesso em: 12 de julho de 2013.

[4] ARAÚJO, L. M. B. Análise Teórica e Experimental de Pilares de Concreto Submetidos à Flexão Normal Composta. Dissertação de Mestrado. UFG, Goiânia, GO, 196p, 2004.

[5] ASSOCIAÇÃO BRASILEIRA DE NORMAS TÉCNICAS. NBR 6118: Projeto de Estruturas de Concreto - Procedimento. Rio de Janeiro, 2014.

[6] NBR 5739: Concreto - Ensaio de Compressão de Corpos-de-prova Cilíndricos. Rio de Janeiro, 2007.

[7] . NBR ISO 6892: Materiais Metálicos - Ensaio de Tração - Parte 1 - Método de Ensaio à Temperatura Ambiente. Rio de Janeiro, 2013.

[8] NBR 7222: Argamassas e Concreto - Determinação da Resistência à Tração por Compressão Diametral do Corpos-de-Prova Cilíndricos. Rio de Janeiro, 2010.

[9] NBR 8522: Concreto - Determinação do Módulo Estático de Elasticidade. Rio de Janeiro, 2008.

[10] . NBR 15823-2: Concreto Autoadensável - Parte 2 - Determinação do Espalhamento e do Tempo de Escoamento - Método do Cone de Abrams. Rio de Janeiro, 2010.

[11] NBR 15823-4: Concreto Autoadensável - Parte 4 - Determinação da Habilidade Passante - Método da Caixa L. Rio de Janeiro, 2010.

[12] NBR 15823-5: Concreto Autoadensável - Parte 5 - Determinação da Viscosidade - Método do Funil V. Rio de Janeiro, 2010.

[13] MELLO, E. L. Concreto Armado: Resistência Limite à Flexão Composta Normal e Oblíqua. 1. ed. Brasília: Editora Universidade de Brasília: FINATEC, p. 224. 2003.

[14] OMAR, M. Y. M. Análise Experimental de Pilares de Concreto Armado Reforçados Usando Concreto Auto-Adensável. Dissertação (Mestrado), UFG, Goiânia, Goiás, 2006.

[15] VIRGENS, J. P. Análise Experimental de Pilares de Concreto Armado, Com Carga Excêntrica, Reforçados Com Chumbadores e Concreto Autoadensável (CAA). Dissertação (Mestrado). EECA/CMEC - UFG. Goiânia, Goiás, 2016.

[16] SAHB, K. F. P. Análise Experimental de Pilares de Concreto Armado Submetidos à Flexo-Compressão, Reforçados com Concreto Auto-Adensável e Chumbadores. Dissertação (Mestrado). P. 171-283. Vol. 3. 2010. EEC/CMEC - UFG. Goiânia, Goiás, 2008. 